International Secretariat: Peter Benenson House, 1 Easton Street, London WC1X 0DW, UK.

Website: http://www.amnesty.org

Secretary-General: Irene Khan (Bangladesh).

\title{
BANK FOR INTERNATIONAL SETTLEMENTS (BIS)
}

Origin. Founded on 17 May 1930, the Bank for International Settlements fosters international monetary and financial co-operation and serves as a bank for central banks.

Aims. The BIS fulfils its mandate by acting as: a forum to promote discussion and facilitate decision-making processes among central banks and within the international financial community; a centre for economic and monetary research; a prime counterparty for central banks in their financial transactions; and an agent or trustee in connection with international financial operations.

Finance. Around 140 central banks and international financial institutions place deposits with the BIS. The total of currency deposits placed with the BIS amounted to SDR200bn. at the end of March 2004, representing 6.5\% of world foreign exchange reserves.

Organization and Membership. There are 55 member central banks. These are the central banks or monetary authorities of Algeria, Argentina, Australia, Austria, Belgium, Bosnia-Herzegovina, Brazil, Bulgaria, Canada, Chile, China, Croatia, the Czech Republic, Denmark, Estonia, Finland, France, Germany, Greece, Hong Kong, Hungary, Iceland, India, Indonesia, Ireland, Israel, Italy, Japan, South Korea, Latvia, Lithuania, Macedonia, Malaysia, Mexico, the Netherlands, New Zealand, Norway, Philippines, Poland, Portugal, Romania, Russia, Saudi Arabia, Singapore, Slovakia, Slovenia, South Africa, Spain, Sweden, Switzerland, Thailand, Turkey, UK and USA, as well as the European Central Bank.

The BIS is administered by a Board of Directors, which is comprised of the governors of the central banks of Belgium, France, Germany, Italy and the UK and the Chairman of the Board of Governors of the US Federal Reserve System as ex officio members, each of whom appoints another member of the same nationality. The Statutes also provide for the election to the Board of not more than nine Governors of other member central banks. The Governors of the central banks of Canada, Japan, the Netherlands, Sweden and Switzerland are currently elected members of the Board.

Headquarters: Centralbahnplatz 2 and Aeschenplatz 1, CH-Basle, Switzerland.

Website: http://www.bis.org

e-mail: email@bis.org

Chairman: Nout Wellink (Netherlands).

Representative Office for Asia and the Pacific: 78th Floor, Two International

Finance Centre, 8 Finance Street, Central, Hong Kong SAR, People's Republic of China.

Representative Office for the Americas: Torre Chapultepec, Rubén Dario 281, Col. Bosque de Chapultepec, 11580 México, D. F., Mexico.

Further Reading

Deane, M. and Pringle, R., The Central Banks. London and New York, 1995

Fleming's Who's Who in Central Banking. London, 1997

Goodhart, C. A. E., The Central Bank and the Financial System. London, 1995

\section{COMMONWEALTH}

The Commonwealth is a free association of sovereign independent states. It numbered 53 members in 2004 . With a membership of $1 \cdot 7 \mathrm{bn}$. people, it represents 